\title{
Aspects of Trope in the Earliest Motets for the Assumption of the Virgin
}

\author{
By Rebecca A. Baltzer
}

The feast of the Assumption of the Virgin, observed annually on 15 August, was the most important saint's feast in the liturgical calendar of Notre Dame of Paris in the Middle Ages. In the thirteenth century, this occasion had a level of ceremonial and ritual splendor equaled only on Christmas, Easter, and Pentecost, for only these four feasts were given the highest liturgical rank, that of annuum festum or festum annuale, as it was variously termed in liturgical calendars at Notre Dame.

The complete round of services for the Assumption of the Virgin began with a Vigil Mass on the eve of the feast and proceeded through the services of First Vespers, Compline, Matins, Lauds, Prime, Terce, the Procession after Terce, Mass, Sext, None, and Second Vespers, finally concluding with Compline on the night of 15 August. Because of its importance, this feast in the thirteenth century also included more than half a dozen chants in polyphonic settings for two and three voice-parts, and it is these items of polyphony, together with their offspring in the form of early Latin liturgical motets, that are the focus of this paper.

On major feasts, the chants that might be provided with a polyphonic setting at Notre Dame included the great responsory and Benedicamus Domino of First Vespers; the third, sixth, and ninth responsories of Matins; the verse of the responsory or large antiphon used in the procession after Terce; ${ }^{1}$ and the Gradual and Alleluia of the Mass. This is a total of eight items, and although no feast seems to have included organum for all eight possibilities, some did for as many as seven. The feast of the Assumption is also one of a number of occasions during the year that included a Vigil Mass, and, though I know of no specific regulations concerning the allowance of a polyphonic Gradual and Alleluia in such Masses, I have assumed their use to be permissible in this instance. Thus the list given in table 1 (on the following page) itemizes in liturgical order all the possibilities for organum on the feast of the Assumption, and if the chant is preceded by an $O$ or $M$ number (for Office and Mass), an organal setting does indeed survive in the repertory of Notre Dame polyphony that has come down to us. ${ }^{2}$

1 Or, on certain occasions, in a procession after Vespers.

2 The $\mathrm{O}$ and $\mathrm{M}$ numbers are those assigned in Friedrich Ludwig, Repertorium organorum recentionis et motetorum vetutissimi stili, vol. 1, Catalog raisonné der Quellen, part 1, Handschriften in Quadrat-Notation (Halle: Max Niemeyer, 1910; repr. as Musicological Studies, vol. 7, Brooklyn, N.Y.: Institute of Mediaeval Music, 1964). 
Table 1

Possibilities for Organum on the Feast of the Assumption

\begin{tabular}{|c|c|c|}
\hline a2 & M 37 & (Vigil) Gradual Propter veritatem W. Audi filia \\
\hline a2 & M 54 & (Vigil) Alleluia Veni electa mea \\
\hline a2, a3 & O 16 & Vespers R. Styrps Yesse V. Virgo dei \\
\hline $\mathrm{a} 2, \mathrm{a} 3$ & BD I & Benedicamus Domino for First Vespers \\
\hline a2 & O 17 & $\begin{array}{l}\text { 3rd Matins R. Veni electa mea W. Specie tua } \\
\text { 6th Matins R. Corde et animo X. Laudem dicite } \\
\text { 9th Matins R. Felix namque X. Ora pro populo }\end{array}$ \\
\hline a2, a3 & O 16 & Processional R. Styrps Yesse W. Virgo dei \\
\hline a2, a3 & M 32 & Gradual Benedicta X. Virgo dei \\
\hline $\mathrm{a} 2$ & M 33 & Alleluia Assumpta est Maria \\
\hline $\mathrm{a} 2$ & M 34 & Alleluia Hodie Maria virgo \\
\hline $\mathrm{a} 2$ & M 35 & $\begin{array}{l}\text { Alleluia Post partum virgo } \\
\text { Alleluia Per te dei genitrix }\end{array}$ \\
\hline $\mathrm{a} 2$ & M 36 & $\begin{array}{l}\text { Alleluia Ora pro nobis } \\
\text { Alleluia Virga Iesse floruit }\end{array}$ \\
\hline $\mathrm{a} 2$ & M 34 & $\begin{array}{l}\text { Alleluia Hodie Maria virgo (In place of a } \\
\text { responsory at Second Vespers) }\end{array}$ \\
\hline
\end{tabular}

I should qualify this list slightly by noting that an Alleluia was sung in a Vigil Mass only if the vigil happened to occur on Sunday; on weekdays the Alleluia was omitted. It can be seen from this list that only two opportunities for organum were passed by-the sixth and ninth responsories of Matins. The Notre Dame repertory does contain polyphony for all the other chants for which organum was allowed.

Why were so many Alleluias included? Though they are all listed in liturgical books as options for the main Mass of the day, we shall see that there are good reasons for assuming that only M 33 and M 34, the Alleluias Assumpta est Maria and Hodie Maria virgo, were likely to have been chosen for performance on the day itself. The Alleluias to be used on the days within the octave of the Assumption were taken from the Vigil Mass and from this group, which in Paris missals and graduals are notated in sequence on the feast day and then merely cued as needed within the octave. $^{3}$

3 The Alleluias Ora pro nobis (M 36), Veni electa mea (M 54), and Post partum virgo (M 35) are prescribed for the first three days of the octave, to be repeated in the same order for the next three days. On one day, Sunday would intervene; Sunday within the octave and the octave itself repeated the 15 August liturgy (sicut in die). Thus there was a polyphonic Alleluia every day during the octave of the Assumption, another mark of the feast's importance. (Following the Alleluia, a prose was also prescribed for each day of the Octave, a feature also not present on ordinary weekdays.) 
The other notable feature about this list of Alleluias is the use of the Alleluia Hodie Maria virgo in Second Vespers in place of a great responsory. Normally Second Vespers did not have a great responsory at all- the service proceeded merely from chapter to hymn and versicle instead of chapter, great responsory, hymn, and versicle as at First Vespers. But because of the great importance of the feast of the Assumption at Notre Dame, this extra mark of liturgical elaboration was made, just as it was also done on Easter Sunday. In both cases, the Alleluia assigned to Vespers is one set in polyphony. And interestingly, the Alleluia Hodie Maria virgo at Second Vespers on the Assumption is followed by a prose (Hac clara die), just as an Alleluia in the Mass would be. ${ }^{4}$

Before we examine in some detail the character of the texts used in the Assumption liturgy, it will be useful to review briefly the history and circumstances of this feast in the medieval church. At the time the Notre Dame School flourished in the twelfth and thirteenth centuries, there were of course four feasts in honor of the Virgin in the liturgy: the Purification on 2 February, the Annunciation on 25 March, the Assumption on 15 August, and the Nativity of the Virgin on 8 September. ${ }^{5}$ Like so many other things in the medieval church, the Marian feasts and the cult of the Virgin were an importation from eastern Christianity into Western Europe. Veneration of the Virgin really began in the fourth century with the establishment of Christmas itself, for the Mother of the Savior was as necessary a character in the Christmas story as her Son. The four Marian feasts mentioned above were introduced into the Roman liturgy in the mid-seventh century, and their purpose was the commemoration of important events in the life of the Virgin.

But these four feasts were not the first in honor of the Virgin. They were preceded by a feast whose focus was upon the paramount characteristic of the Virgin-Mary as the Mother of God. This feast honoring her divine and virginal maternity appeared in the West as early as the midsixth century, and it offered a second perspective on the mystery of the Incarnation: as Christmas celebrated the Incarnation of the Son of God, this feast dwelled upon Incarnation through the Mother of God. ${ }^{6}$

4 On Christmas the prose Hac clara die is also assigned to Vespers in place of the hymn, but without an Alleluia. The Easter Alleluia assigned to Second Vespers is Epulemur in azimis (M 15).

5 Not until the last quarter of the thirteenth century did the feast of the Conception of the Virgin on 8 December begin to be observed in the cathedral of Paris.

6 See Philippe Rouillard, "Marian Feasts," The New Catholic Encyclopedia 9 (1967): 21012. For a detailed study of the early development of Marian feasts, see Dom Frénaud, O.S.B., "Le culte de Notre Dame dans l'ancienne liturgie latine," in Maria: Études sur la Sainte Vierge, 8 vols., ed. Hubert du Manoir de Juaye (Paris: Beauchesne, 1949-71), vol. 6 
Although in Rome this first feast of the Virgin was originally placed on 1 January (emphasizing the connection with Christmas), in Gaul it was placed later in the month. It still appears on 19 January (labeled Natale Sanctae Mariae) in one of the manuscripts of Hesbert's Antiphonale missarum sextuplex, the late ninth-century Gradual of Senlis, which city lies just northeast of Paris. ${ }^{7}$ But liturgical books for the Gothic cathedral of Notre Dame in Paris indicate that this earliest Marian feast was not being celebrated there in the late twelfth century, though some of its texts appear in the liturgy for the Assumption.

At the time it was first observed in the West, the feast of the Assumption concentrated upon the Dormition (or falling asleep) of the Virgin, following the accounts of her death that had appeared in apocryphal literature. It later came to focus upon the glorification of the Virgin, in both soul and body, ${ }^{8}$ and hence the themes of veneration and praise of the Virgin are strong ones in the Assumption liturgy. But things are not exactly as we might expect. Instead of a sharp focus upon the idea of Mary's assumption into Heaven and its consequences for mankind, most of the liturgical texts are either quite general in praise of the Virgin orperhaps to our surprise-they return again and again to what seems a Christmas theme, the idea of the Incarnation. ${ }^{9}$ But we should not regard the idea of Incarnation as exclusive to Christmas; it is one that appeared whenever the Virgin was honored, because Mary's role in the Incarnation was the central fact about her, the starting point for any consideration of her by the faithful, and the ultimate reason for her veneration. Thus the theme of Incarnation may not only recall the Christmas liturgy but may also reflect the perspective of the original Marian feast, Mary as the Mother of God.

And thus when we look at those texts in the Assumption liturgy that were allowable in polyphony (cf. table 1), we find three different emphases. Omitting the Benedicamus Domino from consideration, I would classify the thirteen other texts as follows:

(1961): 157-211. According to Frenaud, as other Marian feasts and the octave of Christmas were added to the Roman liturgy in the seventh century, this first Marian feast was dropped.

7 Dom Réné-Jean Hesbert, ed., Antiphonale missamum sextuplex... d'apres le graduel de Monza et les antiphonaires de Rheinau, du Mont Blandin, de Compiegne, de Corbie, et de Senlis (Brussels: Vromant \& Co., 1935), 31.

8 Daniel F. Hickey, "Dormition of the Virgin," The New Catholic Encyclopedia 4 (1967): $1017-18$.

9 Dom Frénaud has shown that some parts of the Christmas liturgy were in fact borrowed for use on the feast of the Assumption. See "Le culte de Notre Dame dans l'ancienne liturgie latine," especially 207-9. 
Three are general in praise of the Virgin:

$\mathrm{M} 37, \mathrm{M} 54$, and $\mathrm{O} 17$.

Eight either mention or focus entirely upon the ideas of the

Incarnation and Mary the Mother of God:

O 16, 6th responsory, 9th responsory, M 32, M 35, M 36,

Alleluia Per te and Alleluia Virga Iesse.

Only two specifically trope the idea of the Assumption:

the M 33 and M 34 Alleluias.

The three texts that are general in their praise of the Virgin, the Gradual Propter veritatem, the Alleluia Veni electa mea, and the Matins responsory Veni electa mea, in fact share some of the same Biblical verses, a feature that links them together in character. But these three chants were also part of the Common of Virgins in the Paris liturgy, which means that they are not specifically Marian but were used for Marian feasts as well as the feasts of other female saints.

The eight texts that include the themes of Incarnation and Mary the Mother of God approach these ideas from several different directions. The Vespers responsory Styrps Yesse (O 16) takes an explanatory approach to the symbolism of Jesse's rod. This responsory was borrowed from the feast of the Nativity of the Virgin, as its text does suggest. There it is the sixth responsory of Matins, and it is a text known to have been composed by Fulbert of Chartres in the eleventh century. ${ }^{10}$ While the sixth Matins responsory, Corde et animo, is one of praise for the Mother of God, the ninth responsory, Felix namque, seems to touch all the bases, for it includes both praise and petition to the Virgin, and it mentions both the Incarnation and the Assumption. With reference to this last feature, I should point out that this responsory was also the ninth one on the feast of the Nativity of the Virgin, and there the word assumptionem was simply replaced by the word nativitatem.

The Gradual Benedicta (M 32) returns to a single focus upon Mary the Mother of God; it was also the Gradual used for the Nativity of the Virgin, so it is textually not specific to either feast. The Alleluias Post partum, Per te, Ora pro nobis, and Virga Iesse all center upon Mary's role in the Incarnation; Post partum virgo and Ora pro nobis are both petitions for Mary's aid, while Per te and Virga Iesse comment upon her role in salvation.

That leaves us with only two texts, the Alleluias Assumpta est Maria and Hodie Maria virgo (M 33 and M 34), that are one hundred per cent specific to the idea of the Assumption of the Virgin. That is why I think these

\footnotetext{
${ }^{10}$ See J.-P. Migne, ed., Patrologia latina, CXLI (Paris: Garnier Fratres, 1880), col. 345.
} Chant text and translation are in Appendix II. 
two are the ones most likely to have been chosen for use on the feast day itself, Assumpta est in the Mass and Hodie Maria in Second Vespers. ${ }^{11}$ With the exception of several antiphons used in Matins, Lauds, and a couple of the day hours, these two Alleluias are by far the most specific commentaries on the Assumption of any of the chants prescribed in the entire Office and two Masses. It is these two Alleluias, several Office antiphons, and the prayers prescribed that make it unequivocal which Marian event is the real focus of the day.

Returning to our list of fourteen chants that were possibilities for organum in the Assumption liturgy (table 1), we can eliminate the sixth and ninth Matins responsories and the Alleluias Per te and Virga Iesse from further consideration, since no polyphonic settings survive for them. Three of the polyphonic pieces, the responsory Styrps Yesse (O 16), the Benedicamus Domino, and the Gradual Benedicta (M 32), have a three-voice setting as well as a two-voice one. But our next major concern is to see which of these ten chants set in organum have early Latin motets-- and by early, I mean motets in the Florence and second Wolfenbüttel manuscripts ${ }^{12}$ - that on textual grounds would have been suitable for use in the Assumption liturgy.

Four of these organa can be dropped immediately, for they inspired no motets, either Latin or French: the Matins responsory Veni electa mea (O 17), and the Alleluias Assumpta est Maria (M 33), Post partum virgo (M 35), and Ora pro nobis (M 36). That leaves six polyphonic pieces (three of which have a three-voice setting also) for which there are early motets: $\mathrm{M} \mathrm{37,} \mathrm{M}$ 54, O 16, BD I, M 32, and M 34. Table 2 lists a total of nineteen early Latin motets on these six chants that seem appropriate for liturgical use as a kind of polyphonic trope during the performance of the parent organum. ${ }^{13}$

${ }^{11}$ In thirteenth-century Paris missals and graduals, the Alleluia Hodie Maria virgo after mid-century moved from the end of the list to second place, immediately following the Alleluia Assumpta est, as if to give emphasis to the fact that these two texts were the most "proper" to the day. (This same order is also found among the organa in the Florence manuscript.) The Alleluia Hodie Maria was never notated in breviaries at Second Vespers on the Assumption; it was simply prescribed in the rubrics and would have to be retrieved from a missal or gradual.

${ }^{12}$ For photographic facsimiles, see Luther A. Dittmer, ed., Facsimile Reproduction of the Manuscript Firenze, Biblioteca Mediceo-Laurenziana, Pluteo 29, 1, 2 vols., Publications of Mediaeval Musical Manuscripts, no. 10 (Brooklyn, N.Y.: Institute of Mediaeval Music, [196667]); and idem, ed., Facsimile Reproduction of the Manuscript Wolfenbüttel 1099 Helmstadiensis (1206): $W_{2}$, Publications of Mediaeval Musical Manuscripts, no. 2 (Brooklyn, N.Y.: Institute of Mediaeval Music, 1960).

${ }^{13}$ Motet numbers, manuscript sigla, and other source information are as given in Friedrich Gennrich, Bibliographie der ältesten französischen und lateinischen Motetten, Summa musicae medii aevi, no. 2 (Darmstadt: published by the author, 1957). Some discoveries 


\section{Table 2}

Motets for the Assumption of the Virgin

15 August Annuum festum with vigil

M 37 Gradual for Vigil Mass: Propter veritatem W. Audi filia

Motet 448: $O$ Maria, maris stella / Veritatem

a3 in $F, 397 \mathrm{v}(1,25) ; W_{2}, 125(1,3)$; and $C h$ [no source clausula]

Other versions:

a3 French (450) in $W_{2}, 135(1,14)$

a2 in ArsA, ArsB, Ca, OLy, and ErfC

a3 Latin double (449 Tr) in $\mathrm{Cl}, \mathrm{Mo}, \mathrm{Ba}$, Bes, and $\mathrm{Da}$

a4 (448; 449 Qua) in $H u$

a3 (449a Tr) in $H u$

Motet 478: Audi, filia egregia / Filia

a2 in $F, 408 \mathrm{v}(2,30)$ [no source clausula; unicum]

M 54 Alleluia for Vigil Mass (if Sunday): Alleluia Veni electa mea

Motet 529: Quia concupivit vultum / Quia concupivit rex a2 in $F, 405(2,19)$, and $W_{2}, 152 \mathrm{v}(2,14)$

O 16 Vespers responsory Styrps Yesse W. Virgo dei

Motet 647/648: Stirps Yesse / Virga cultus / Flos filius eius [= 649]

a3 double motet in $F, 409 \mathrm{v}(2,33-34)$ [a3 source clausula]

Other versions:

a3 French double $(650,651)$ in $W_{2}, 206 \mathrm{v}(3,13), R$, and $N$

a4 French triple $(652,650,651)$ in $\mathrm{Mo}$ and $\mathrm{Cl}$

a2 French (651) in $\mathrm{Ca}$

a3 Latin double $(653,654)$ in $B a$ and $H u$

a2 Latin (654) in $\mathrm{Bol}$ and $\mathrm{Ca}$

Motet 649: Candida virginitas / Flos filius eius [= Motet 648]

a2 in $W_{2}, 145 \mathrm{v}(2,3)$, and $L o C$ [a3 source clausula]

Motet 665: Flos ascendit de radice / Flos filius eius

a2 in $W_{2}, 161(2,31)$

made since Gennrich's work are noted in Norman E. Smith, "From Clausula to Motet: Material for Further Studies in the Origin and Early History of the Motet," Musica disciplina 34 (1980): 29-65. Published transcriptions are readily available in Gordon A. Anderson, The Latin Compositions in Fascicules VII and VIII of the Notre Dame Manuscript Wolfenbüttel, Helmstadt 1099 (1206), vol. 2, Transcriptions, Musicological Studies, vol. 24, part 2 (Brooklyn, N.Y.: Institute of Mediaeval Music, 1976); and Hans Tischler, The Earliest Motets (to circa 1270): A Complete Comparative Edition, 3 vols. (New Haven: Yale University Press, 1982). Each motet listed in table 2 is based on a two-voice clausula unless otherwise noted. Duplum, Triplum, and Tenor are abbreviated as Du, Tr, and T. 


\section{Festschrift for ERnest SANDERS}

Other versions:

a2 French (663) in $W_{2}, 226(4,29)$, and $L o C$

a3 French double $(664,663)$ in $\mathrm{Mo}$ and $\mathrm{Cl}$

Motet 669: Ave, rosa novella / Flos filius eius

a2 in $W_{2}, 178 \mathrm{v}(2,51)$ [no source clausula; unicum]

BD I Benedicamus Domino at First Vespers

Motet 655: Virgo singularis / [Domino]

a2 in $F, 414(2,45)(\mathrm{T}=E[i u s]$ from $\mathrm{O} 16)$

Motet 760a: Ave gloriosa mater / (Domino) [no source clausula] a2 conductus (Du and Tr only) in $W_{2}, 140$ (1, conductus 3) Other versions:

a3 as conductus motet (score format with text under T) in $\mathrm{LoHa}$ a3 double motet $(760 \mathrm{~b}, 760 \mathrm{a})$ in $\mathrm{Cl}, \mathrm{Mo}, \mathrm{Ba}, \mathrm{Hu}$, and $\mathrm{Bes}$ a2 conductus ( $\mathrm{T}$ and $\mathrm{Du}$ ) in $O L y$ and $D a$ a2 motet in $A r s B, M \ddot{u} C$, and $M a z$ al (texted $\mathrm{Du}$ ) in Don

O 16 Procession after Terce: Styrps Yesse W. Virgo dei

Motet 660: $O$ vere lucis aurora / Flos filius eius a2 in $W_{2}, 175 v(2,45)$ [source clausula in StV] Other versions: a3 French double $(657)$ in $W_{2}, 208 \mathrm{v}(3,16)$ (Tr music lacking) a2 French $(659)$ in $W_{2}, 226 \mathrm{v}(4,31)$ a3 French double $(658,657)$ in $M o$ and $B a$ a4 French triple $(658,659,657)$ in $\mathrm{Mo}$ and $\mathrm{Cl}$

Motet 670: Virga, virgo regia / Flos filius eius a2 in $W_{2}, 189 \mathrm{v}(2,76)$ [no source clausula] Other version: a2 French $(667)$ in $W_{2}, 242(4,66)$ [with musical variants]

M 32 Gradual Benedicta W. Virgo dei

Motet 411: $O$ Maria, mater pia, mater / Virgo [= Motet 412] a3 in $F, 393(1,18)$ a2 in $W_{2}, 183 \mathrm{v}(2,64)$ and $O L y$ Other versions: a3 Latin double $(411,412)$ in $M \ddot{u} B$ a2 French (413) in $W_{2}, 251 \mathrm{v}(4,87)$

Motet 412: Virgo plena gratie / Virgo [= Motet 411] a3 in $W_{2}, 129 \mathrm{v}(1,9)$ a2 in $W_{2}, 154 \mathrm{v}(2,18)$ 
Other versions:

a3 Latin double $(411,412)$ in $M \ddot{u} B$

a2 French (413) in $W_{2}, 251 v(4,87)$

Motet 417: Benedicta regia / Virgo

a2 in $W_{2}, 145(2,2)$ and $178 \mathrm{v}(2,52)$ [no source clausula]

Other version:

a2 French $(418)$ in $W_{2}, 220 \mathrm{v}(4,16)$ and $241 \mathrm{v}(4,65)$

Motet 420: Mellea vite vinea / Virgo

a2 in $W_{2}, 190(2,78)$

Other version:

a2 French (419) in $W_{2}, 236(4,53)$, and $M o$

Motet 422: O pia, capud hostis / Virgo

a2 in $W_{2}, 191 v(2,82)$ [no source clausula]

Other version:

a2 French $(421)$ in $W_{2}, 248 \mathrm{v}(4,80)$

M 34 In place of responsory at Second Vespers: Alleluia Hodie Maria virgo

Motet 437: Flos de spina mimpitur / Regnat

a3 in $F, 393$ v $(1,19)$

a2 in $W_{2}, 147(2,6)$ and $180(2,56)$

Other versions:

a2 in $M a$ ( $\mathrm{T}$ missing) and $M \ddot{u} C$ (T missing)

a3 mixed double $(438,437)$ in $M o$ and Bes

Motet 441: Hodie Marie concurrant / Regnat

a3 in $F, 394 \mathrm{v}(1,21)$

Other version:

a2 conductus in $M a$ ( $\mathrm{Tr}$ and Mo; no $\mathrm{T}$ )

Motet 442: Rex pacificus unicus / Regnat a2 in $F, 402 \mathrm{v}(2,10)$, and $W_{2}, 153(2,15)$

Certainly some would work better than others, for both textual and musical reasons, but to summarize, there are:

2 motets for the Gradual Propter veritatem (M 37)

1 motet for the Alleluia Veni electa mea (M 54)

6 motets for the responsory Styrps Yesse (O 16)

2 motets for the Benedicamus Domino (BD 1)

5 motets for the Gradual Benedicta (M 32)

3 motets for the Alleluia Hodie Maria (M 34).

We are left with no motets for the Matins service. This phenomenon, however, is not confined just to the feast of the Assumption, for among 
all the surviving Office motets in $F$ and $W_{2}$, with a single possible exception, ${ }^{14}$ none seems originally intended for use in Matins. The parent responsory is used liturgically either as the Vespers responsory, the processional responsory, or some combination of these two with an additional use in Matins. In other words, there is no early Office motet based upon a responsory used only in Matins; such motets exist only with a Vespers or processional responsory (or both) for a parent. Only in later motet sources such as the Montpellier and Bamberg manuscripts do motets with tenors solely from Matins responsories begin to occur.

It is at this point that we would be wise to look not just at the text of the parent chant in assessing the "tropic" character of a motet text, but also at the surrounding liturgical context. Let us begin our consideration with the Proper texts of the Vigil Mass (reproduced as Appendix I.A) to see what the broader liturgical context was for motets for the Gradual and Alleluia of the Vigil Mass. It is noteworthy that except for the first part of the Alleluia verse, the texts of the Proper chants in the Vigil Mass - the Introit, Gradual, Alleluia, Offertory, and Communion-are all taken from Vulgate Psalm 44 (Eructavit cor meum), and, in the Paris liturgy, all were part of the Common of Virgins. Yet they can serve the Virgin Mary as well as lesser saints.

The Introit Vultum tuum with its verse Enctavit cor meum was the one prescribed in the original Marian feast of Mary the Mother of God, and it seeks to establish her preeminent place: "All the rich among the people shall implore thy countenance; after her shall virgins be brought to the King: her neighbors shall be brought to thee in gladness and rejoicing. W. My heart hath uttered a good word: I speak my works to the King." The Offertory uses much of the same text as the Introit antiphon, and the Communion reads, "You have loved righteousness and hated injustice; therefore God your God has anointed you." The Epistle or lesson from Chapter 24 of Ecclesiasticus reads:

From the beginning and before the world I was created, and unto the world to come I shall not cease to be, and in the holy dwelling-place I have ministered before him. And thus I was established in Syon, and in the holy city likewise I rested, and in Jerusalem was my power. And II took root in an honorable people, and in the portion of my God his inheritance, and my abode is in the full assembly of saints.

${ }^{14}$ See below, Motet 665: Flos ascendit de radice / Flos filius eius. 
The Gospel is a famous passage from St. Luke that directly praises the Virgin: "At that time, as Jesus was speaking to the multitudes, lifting up her voice, a certain woman from the crowd said to him, 'Blessed is the womb that bore thee, and the breasts that thou sucked.' But he said, 'Blessed rather are those who hear the word of God and keep it."'

Of the three prayers, the Collect, the Secret, and the Postcommunion, it is the Secret that most directly addresses the idea of the Assumption: "O Lord, in the presence of Thy mercy, great is the prayer of the Mother of God, whom Thou didst take up out of this present world that she might boldly intercede for our sins before Thee." One can see that such an idea leads very naturally to motet texts that petition the Virgin to intercede for penitent sinners. The Collect and the Postcommunion both sound the Incarnation theme of Mary the Mother of God; while the Collect mentions the impending feast without being specific, the Postcommunion refers to the requiem of the Mother of God.

We have noted that the Gradual and Alleluia in the Vigil Mass were used for other saints besides the Virgin. When we look in Appendix II at the text of the Alleluia Quia concupivit vultum (Motet 529), we can see that it is not specific to the BVM but would have been usable on the feast of any virgin for whom the Alleluia Veni electa (M 54) was prescribed. I suspect that this is because the Alleluia would have been used at the Assumption Vigil only once every six or seven years when the day fell on Sunday. Given that circumstance, it was simply easier to use a "common" motet with a "common" Alleluia. Nonetheless, the text clearly tropes the tenor words, though the motet did not go beyond its two earliest appearances in $F$ and $W_{2}$.

In contrast to this "common" motet, both of the motets on the Gradual Propter veritatem (M 37) - one from the respond and one from the verseare specifically in honor of the Virgin. Neither one is based upon a clausula, yet they could hardly be more different. O Maria, maris stella has a text that looks much like a conductus. It is wonderfully regular, with alternating rhymes, and the first-mode upper parts (over a fifth-mode tenor) are regularly disposed in four-measure musical phrases. The poetry offers a large serving of Marian epithets, and the praise culminates in a petition for the Virgin's aid. Not until the last word is there a tropic reference to the tenor word Veritatem, and nowhere is there an explicit reference to the Assumption. Both in musical quality and in popularity, this was a hugely successful piece; even with the original triplum replaced by a new melody in the sixth rhythmic mode, this is one of the best motets in the repertory.

The other M 37 motet, Audi, filia egregia, an unicum in the Florence manuscript, is much more typical of the early motet. Its lines of irregular 
length all end in an $-a$ assonance that creates an aural trope with the end of the tenor word, filia, and the beginning words of the motet clearly relate to the beginning words of the Gradual verse. Its text is a bit more learned in expression of praise and petition than the facile but effective epithets of $O$ Maria, maris stella. Audi, filia egregia, however, is a second-mode piece that changes tenor patterns midway through; the phrasing in the motetus often works against that in the tenor, and this composition prompted no descendants.

We have already noted that the responsory Styrps Yesse $(\mathrm{O} 16)$ was originally borrowed from the feast of the Nativity of the Virgin, where it was the sixth responsory of Matins, for use as the Vespers responsory and the processional responsory on the Assumption. Undoubtedly this transfer was made well before Leonin's time. Though the text relates obliquely to the Nativity of the Virgin, the primary themes are those of Incarnation and Mary the Mother of God, and the six early Latin motets on this chant do not alter those emphases.

When we look at the position of Styrps Yesse within the context of First Vespers of the Annunciation (see Appendix I.B), there is nothing in this service, either, to deflect the attention from the idea of Incarnation effected through the Virgin. Several of the antiphons praise the Virgin with verses from the Song of Songs. The Chapter uses the beginning two verses of the Mass lection for the day, again from Chapter 24 of Ecclesiasticus: "In all things I sought rest, and I shall abide in the inheritance of the Lord. Then the Creator of all things commanded and spoke to me; and He that made me rested in my tabernacle." The hymn Quem terra returns to the Incarnation theme; one of its stanzas and the Magnificat antiphon that follows bring in the idea of the Virgin as the restorer of all that was lost by Eve: though Eve closed the gate of paradise, the Virgin has opened it again. The prayer after the Magnificat is the same as the Collect from the Vigil Mass.

The six motets derived from Styrps Yesse are all built on the long melisma from the end of the verse, Flos filius eius. The first of these, which is based on a three-voice clausula in first mode, is a rare double motet in the Florence manuscript. Both of its texts are excellent glosses upon the parent responsory text, carefully elaborating and expanding its ideas, and the work went through a number of later reworkings in both French and Latin. Without the triplum, this music also serves for the two-voice motet Candida virginitas in $W_{2}$. In stating that the Virgin's chastity has opened the halls of heaven, the text, like that of the Magnificat antiphon, points to the Virgin's role in salvation.

Motet 665 , Flos ascendit de radice, is also a first-mode piece that carefully tropes the chant at beginning and end. In between, however, as Gordon 
Anderson interpreted it, the text urges the Virgin to intercede for the Jews if they show signs of conversion..$^{15}$ This is the one motet that may be an exception to the idea that no early motets were composed for use in the Matins service. The responsory Styrps Yesse (O 16) was prescribed as the sixth Matins responsory on the Nativity of the Virgin, as we have noted. In that Office, both the fifth and sixth lessons of Matins are commentaries upon the prophecies of the Messiah from the book of Isaiah, and the fifth (not the sixth) lesson concludes with the words:

Egredietur inquid virga de radice Yesse: et flos de radice eius descendit, et requiescet super eum spiritus domini.

The parallel with the beginning of Flos ascendit de radice and with the text of the responsory Styrps Yesse seems more than mere happenstance. ${ }^{16}$

The fourth motet on the Flos filius tenor, Ave, rosa novella, is an unicum in $W_{2}$. Although only two dozen measures long, it is both textually and musically defective in its sole copy; Gordon Anderson proposed one possible solution and Hans Tischler proposed two in published transcriptions. It is Anderson's emendation of the text that seems to relate the work more specifically to the Assumption.

I have suggested that the last two Flos filius motets, $O$ vere lucis aurora and Virga, virgo regia, might well have been used when the $\mathrm{O} 16$ responsory was sung as part of the procession after Terce. Normally this procession, immediately prior to the main Mass of the day, took place only on Sunday, but on the Assumption, there was a procession after Terce regardless of the day of the week. As the procession left the choir, the respond of a responsory proper to the day was sung; the procession then came to a halt and made a station before the cross atop the choirscreen. Here the verse of the responsory was sung, and on the Assumption, the liturgical rubrics tell us that the verse of $\mathrm{O} 16$ was either organized (i.e., performed polyphonically) or sung by six singers. ${ }^{17} \mathrm{It}$ is here, as part of the polyphonic verse, that I propose the possible use of our last two Flos filius

15 Gordon A. Anderson, The Latin Compositions in Fascicules VII and VIII of the Notre Dame Manuscript Wolfenbüttel, Helmstadt 1099 (1206), vol. 1, Critical Commentary, Translation of the Texis and Historical Observations, Musicological Studies, vol. 24, part 1 (Brooklyn, N.Y.: Institute of Mediaeval Music, [1971]), 187.

${ }^{16}$ The fifth responsory of Matins on the Nativity BVM is Corde et animo, which is the sixth responsory on the Assumption. It frequently happened that the lessons of Matins were compressed or shortened in the later Middle Ages, disturbing the original correspondence between lesson and responsory. In the Paris liturgy this phenomenon is observable within the course of the thirteenth century itself.

${ }^{17}$ For more on such rubrics, see my 1985 paper, "Performance Practice, the NotreDame Calendar, and the Earliest Latin Liturgical Motets," in Das musikgeschichtliche Ereignis 
motets. After the responsory, there was a versicle sung by the boys, followed by a Proper prayer. Nearly every procession at Notre Dame then terminated with a commemoration of the Virgin, since this was the Virgin's church. This commemoration consisted of a Marian antiphon sung as the procession reentered the choir, followed by a versicle and a prayer. Mass began immediately thereafter.

Both motets are petitions with a somewhat votive character that seems appropriate for the processional commemoration of the Virgin. O vere lucis aurora shows a delight in the kind of learned word play more common in the conductus repertory: lucis/lucida, aurora/aura rora, placida/pacida, decora/decor ora, and so on. But its text is far less of a trope than that of Virga, virgo regia. This latter text, which explicitly tropes the chant at beginning and end, also features that early $-a$ assonance at the end of each line but two, and those two-pius and flos filius-produce the sound of the tenor words filius eius. Both motets are short, first-mode compositions that also exist in French-texted versions, though the music of $O$ vere lucis aurora circulated longer and more widely in the later thirteenth century.

The melody of Benedicamus Domino I in the Notre Dame repertory is borrowed from the Flos filius eius melisma of $\mathrm{O} 16$, and two motets on this tenor are appropriate for use at First Vespers on Marian feasts. The first of these, Virgo singularis, has a fifth-mode tenor $(2 \mathrm{si} / 3 \mathrm{li} /$ ) and a firstmode upper voice regularly disposed in two- or four-measure phrases throughout, which allows a poetic regularity not terribly frequent in the early motet repertory. The first eight lines seem to be two four-line stanzas with the same alternating rhyme scheme, while the remaining eleven lines are divided four, four, and three, and all end with an -ovowel sound. Though the scribe of the Florence manuscript began to label the tenor of this motet E[ius], the last word of the verse from O 16, and though its text uses the first word (Virgo) twice, I have nonetheless listed this as a Benedicamus piece, since the source clausula is Domino no. 11 in $F$. The motet's emphasis on the -o vowel sound at the end of most lines makes it a kind of aural trope of the tenor word Domino as well, though there is no barrier to its further use in O 16 with the tenor Eius. Since the text is not specific to the Assumption, this motet could serve as a Benedicamus piece on any feast of the Virgin.

Similarly, the text of Ave, gloriosa mater is general enough to serve on any Marian feast, though the reference to the Virgin as mistress of heaven

'Notre-Dame,' ed. Wulf Arlt and Fritz Reckow, Wolfenbütteler Forschungen, no. 38 (Wolfenbüttel: Herzog August Bibliothek, forthcoming). Processional rubrics for the Assumption and the Nativity BVM are among those traced in Baltzer, "How Long Was Notre-Dame Organum Performed?" in Beyond the Moon: Festschrift Luther Dittmer, ed. Bryan Gillingham and Paul Merkley (Ottawa: Institute of Mediaeval Music, 1990), 118-43. 
(celi domina) implies that the event of her Assumption has taken place. This excellent and lengthy first-mode composition has four eight-line stanzas that are regularly disposed in two-measure musical phrases; the resemblance to a conductus is not accidental. In $W_{2}$ this work appears as exactly that, a two-voice conductus without the liturgical tenor; its numerous appearances as a motet are all in later or peripheral sources. Though Friedrich Ludwig believed that the $W_{2}$ conductus version was the first, subsequent scholars have argued that the polyphonic archetype was probably a conductus motet with the Domino tenor included; MS Harley 978 in the British Library presents it both ways. ${ }^{18}$ But either as a motet included in the organum or as a conductus substituted for it, Ave gloriosa is a Benedicamus piece that is splendidly suited for all four feasts of the Virgin.

Our remaining motets for the Assumption have tenors taken from the Gradual Benedicta (M 32) and the Alleluia Hodie Maria virgo (M 34), so a brief look at the Mass Propers for both the Assumption (Appendix I.C) and the Nativity of the Virgin (Appendix I.D) is in order, since the Gradual and several other items were the same on both feasts. The Introit Gaudeamus was one of the most frequently used in the Paris liturgy, appearing more than a dozen times a year. Its reference to the Assumption was changed to the Nativity of the Virgin for its use on that day, but as part of the Common of Virgins it was also prescribed for a number of other female saints. In addition, it was sung on All Saints' (1 November), the Finding of Stephen and His Companions (3 August), and the newly established feast of the Reception of the Relics at Notre Dame (4 December). The Epistle (lection) from Chapter 24 of Ecclesiasticus overlaps that used in the Vigil Mass, and a continuation of the same chapter was prescribed for the Nativity of the Virgin. Though in the Biblical context this is the discourse of Wisdom, one can see that the elaborate similes in both readings could have provided some precedent (if any was needed) for the flood of Marian epithets in motets usable on either of these two feasts.

The prose Letabundus that followed the series of Alleluias in the Assumption Mass is one of transitional style from the eleventh century. Since it, too, deals with the theme of Incarnation, it is not surprising to find that in the Paris liturgy this piece was prescribed for Christmas as well as for the Assumption. Similarly, the prose Hac clara die that followed

18 Ludwig, Repertorium, vol. 1, part 1, p. 180. This composition has been much discussed; see the bibliography and the observations in Anderson, The Latin Compositions, 1:6877. A stemma for the various versions of Ave gloriosa is offered in James H. Cook, "Manuscript Transmission of Thirteenth-Century Motets," 2 vols. (Ph.D. diss., The University of Texas at Austin, 1978), 1:65-81. 
the Alleluia Hodie Maria virgo in Second Vespers for the Assumption was also used in Christmas Vespers, as well as in the Mass for the Nativity of the Virgin. And just as two of the Assumption Alleluias were among the proper items most specific to the day being celebrated, the same was true of the Alleluia Nativitas prescribed for the feast of Mary's Nativity. It is the Alleluias and the prayers-the Collect, Secret, and Postcommunionthat are the most direct and explicit about the day on both the Assumption and the Nativity of the Virgin.

The Gospel in the Mass for the Assumption describes the visit of Jesus to the home of two sisters, Martha and Mary. While Martha busied herself serving, Mary put first things first and sat at the feet of Jesus. When Martha complained of no help from her sister, Jesus replied to her, "Mary hath chosen the better part, which shall not be taken from her." ${ }^{19}$ Following the Gospel, the three choices for the Offertory all address the Virgin's role in the Incarnation, as does the third option for the Communion, Beata viscera. The second Communion chant stresses Mary's inviolate virginity. But the first Communion, Regina mundi, combines a petition for aid with a reminder of the Virgin's role in the Incarnation at the same time that it addresses her as queen and mistress of the world, implying that her heavenly glorification is complete. Thus this Communion and the first of the three Offertories, Beata es, virgo Maria, reappear as the prescribed chants, without option, in the Mass for the Nativity of the Virgin.

As we have noted, the focus of the Gradual Benedicta is upon Mary the Mother of God, with no reference to either her Assumption or her Nativity. One might suppose that the composers of motet texts on this chant would take advantage of the opportunity to make their trope more specific to the feast at hand, but such was not really the case. Of the five motets on the tenor Virgo (the first word of the Gradual verse), only the first composition mentions the Virgin as being upon the throne of Heaventhe sole explicit reference to the Assumption.

This motet, $O$ Maria, mater pia, mater salvatoris, shares its music (firstmode upper voices over a fifth-mode tenor) with the second Gradual motet, Virgo plena gratie. In comparing their texts alone, we would never suspect that they were fitted to the same music, for equivalent lines do not all have the same number of syllables. The first motet alternates lines of eight and six syllables: "O Maria, mater pia, / Mater salvatoris." But the second piece begins with two seven-syllable lines: "Virgo plena gratie, / Thesaurus largitatis." The trick is that "Thesaurus largitatis" begins with a pick-up beat that in effect shifts the syllables to eight plus six. My

19 The Gospel for the Nativity of the Virgin is the Liber generationis, Matthew 1:1-16. 
impression from such details is that the second motet, Virgo plena gratie, is indeed secondary and that $O$ Maria, mater pia was the first text to be added to the clausula.

The third Virgo motet, Benedicta regia, is one of those intriguing pieces that for some reason appears four times in $W_{2}$, twice with the same Latin text and twice again with the same French text. It is a second-mode piece without a clausula source, and its fussy, ornamental, small note values show all the hallmarks of a work whose French text came first. Yet the Latin text carefully tropes the parent Gradual Benedicta with the words Benedicta, virgo venerabilis, tactus, and quem non capit. The latter half of this text may be intended as a somewhat oblique reference to Mary as Queen of Heaven when it says, "among all creatures thou holdest the highest place" and speaks of her as leading men to the joys of the kingdom of heaven.

The next Virgo motet, the first-mode Mellea vite vinea, at its very end makes reference to the start of the Gradual verse, but the beginning words, Mellea vite vinea-"honey-sweet vine of life"-seem to be inspired by the text of the Epistle for the Nativity of the Virgin. It begins, "Like a vine I put forth the sweetness of perfume, and my flowers [are] the fruit of honor and integrity." And a few lines later: "My breath [or my soul] is sweeter than honey, and my inheritance is better than honey and honeycomb." In its Latin version, then, this motet may have been intended for the Nativity of the Virgin rather than the Assumption, but like the previous one, its French version probably came first.

The last Virgo motet, O pia, capud hostis, is another second-mode piece that contrafacts an earlier French version, one newly-composed without a clausula model. The first three lines of the Latin text echo a passage from the $\mathrm{O} 16$ motet Candida virginitas (Motet 649), which states, "O Chastity, thou hast crushed the head of the enemy." O pia, capud hostis makes no specific reference to its parent chant text, but the line lucem das de superis - "thou dost give light from above"-implies Mary's position as Queen of Heaven following the Assumption.

The last three motets, on the tenor melisma Regnat from the Alleluia Hodie Maria virgo (M 34), are, like the Alleluia itself, wonderfully specific about the occasion for their use. Even someone without knowledge of the parent chant would have no difficulty in determining that these motets celebrate the Assumption of the Virgin. The first of the three, Flos de spina rumpitur, is a piece in the classic Perotinian style of the early motet, with a fifth-mode tenor $(2 \mathrm{si} / 3 \mathrm{li} /$ ) and trochaic upper parts. It is a threevoice conductus motet in the Florence manuscript and appears twice as a two-voice piece in $W_{2}$. In the Madrid and $M \ddot{u} C$ manuscripts, the tenor is left off to form a two-voice conductus. But it is pleasing to note that the 
quality of this motet was sufficiently recognized in the later thirteenth century that it was included as a mixed double motet in both the Montpellier manuscript and the Besançon manuscript, of which only the index survives. ${ }^{20}$ The text of Flos de spina rumpitur, particularly the beginning, is in fact like some conductus texts that delight in a kind of abstract meditation on a theological paradox. One almost has the impression that the opening lines trope the responsory Styrps Yesse (O 16), though the final three words, cum filio regnat, are a definite recall of the words cum Christo regnat in the Alleluia verse. Sixty-four measures long, Flos de spina is just one measure shorter than the Benedicamus motet Ave gloriosa; they plus the 64measure final motet are by far the longest of the nineteen motets under consideration.

Also longer than most is the 40-measure Hodie Marie concurrant, whose Regnat tenor is laid out in duplex longs. This, too, is a three-voice conductus motet in $F$ (with first-mode upper parts) that becomes a twovoice conductus without tenor in the Madrid manuscript. It is the beginning of this text that clearly tropes the Alleluia Hodie Maria, though the words virgo and regnat in lines six and seven also refer to the chant verse. In the words of this motet, each separate thought has its own two-syllable rhyme: -ie for the first seven lines; - ia followed by -io for the next eight; and -ura for the last three. The thought goes from praise of the Queen of Heaven on the day of her Assumption to petition for her intercession on behalf of her devoted servants.

The last motet, the two-voice Rex pacificus found only in $F$ and $W_{2}$, is the only one to have a motetus in third and second mode. ${ }^{21}$ It is precisely the same length as the first Regnat motet, Flos de spina, because they use the same fifth-mode tenor pattern, one that is particularly associated with Perotin. After a small bow to the idea of Incarnation, the text focuses entirely on the Assumption; it combines a certain didactic quality with praise. Unlike most, it does not include a petition; it is simply a thoughtful reflection upon the day, and it concludes with the tenor word Regnat. As the final motet that might gloss the liturgy of the Assumption at Second Vespers, Rex pacificus strikes a fitting note upon which to end the feast itself.

${ }^{20}$ For information on this large but now lost source, see Gennrich, Bibliographie, xxvxxvi.

21 To be more precise, I should state that the motetus changes from third to second mode beginning in $\mathrm{m}$. 21, though some second-mode phrases continue to end with ternary longs as in third mode. I have elsewhere pointed to this piece (in its clausula form) as one in which second mode is "caught in the act," so to speak, of being born, the result of the consistent fracture of the ternary long of third mode. 
With a last look at the list of Assumption motets in table 2, we can come to some summary conclusions. We observed that three of the five motets on the Gradual Benedicta (M 32), Benedicta regia (Motet 417), Mellea vite vinea (Motet 420), and O pia, capud hostis (Motet 422), appear to be contrafacts of French originals; in this sense they are liturgical afterthoughts, though they may work perfectly well in the liturgy. Three of the $\mathrm{O} 16$ motets, Flos ascendit de radice (Motet 665), $O$ vere lucis aurora (Motet 660 ), and Virga, virgo regia (Motet 670), also seem to have French originals. Needless to say, all six of these motets are found in $W_{2}$ rather than in $F$. And at least two of them, Flos ascendit (Motet 665) and Mellea vite vinea (Motet 420), may have been composed for the Nativity rather than the Assumption of the Virgin.

Two of the nineteen motets are unica, the M 37 motet Audi, filia egregia in $F$ and the $\mathrm{O} 16$ motet Ave, rosa novella in $W_{2}$. Those two plus four others have no source clausula. Here it is interesting to observe that two of the pieces without a source clausula are among the most successful, both qualitatively and distributionally: the M 37 motet $O$ Maria, maris stella and the Benedicamus piece Ave gloriosa mater. In contrast to this, eight of the nineteen motets do not go beyond copies in $F$ or $W_{2}$; they have no descendants and thus remain "the earliest motets."

Perhaps the most noteworthy finding of this study is that the earliest motets as tropes do not function in quite the same way as tropes themselves. We are familiar with tropes that make what is implicit in the thing troped more explicit in the trope itself, but these "tropic" motets do not work that way. Instead, they are like good children: they take their cue from their parents and do as the parent chants do. If the chant is unequivocally proper to the feast at hand, as in the case of the Alleluias, so are the offspring motets; if the chant manifests a more general theme, so do the motets. In the case of motets for the Virgin, the most striking feature is the pervasiveness of the idea of Mary as the Mother of Godthe Marian aspect of the Incarnation-whatever the specific feast may be. This idea of Mary the Mother of God is a kind of ever-present nimbus in any contemplation of the Virgin; it dominates every other aspect about her. In so doing, it not only focused the medieval cleric's attention on the most important reality about her; it serves as a link for us to what was the earliest liturgical practice in the veneration of the Virgin. 


\section{Appendix I}

\section{A. Vigil Mass for the Assumption of the Virgin}

INTROIT: Vultum tuum deprecabuntur omnes divites plebis: adducentur regi virgines post eam: proxime eius adducentur tibi in leticia et exultatione. W. Eructavit cor meum verbum bonum: dico ego opera mea regi. Gloria patri.

ORATIO: Deus qui virginalem aulam beate Marie in qua habitares eligere dignatus es: da quesumus: ut sua nos defensione munitos iocundos faciat sue interesse festivitati. Qui vivis.

EPISTLE: Lectio libri sapientie [Ecclesiasticus 24:14-17].

$\mathrm{Ab}$ initio et ante secula creata sum: et usque ad futurum seculum non desinam, et in habitatione sancta coram ipso ministravi. Et sic in Syon firmata sum: et in civitate sanctificata similiter requievi, et in Jerusalem potestas mea. Et radicavi in populo honorificato: et in partes dei mei hereditas illius, et in plenitudine sanctorum detentio mea.

GRADUAL: Propter veritatem et mansuetudinem et iusticiam, et deducet te mirabiliter dextera tua. X. Audi, filia, et vide, et inclina aurem tuam, quia concupivit rex speciem tuam.

ALLELUIA: [used only if Sunday] Veni electa mea et ponam te in thronum meum, quia concupivit rex speciem tuam.

GOSPEL: Secundum Lucam [Luke 11:27-28]. In illo tempore: Factum est dum loqueretur Ihesus ad turbas: extollens vocem quedam mulier de turba dixit illi: Beatus venter qui te portavit: et ubera que suxisti. Ac ille dixit: Quinimmo: Beati qui audiunt verbum dei: et custodiunt illud.

OFFERTORY: Offerentur regi virgines: proxime eius offerentur tibi in leticia et exultatione: adducentur in templum regi domino.

SECRET: Magna est domine apud clementiam tuam dei genitricis oratio, quam idcirco de presenti seculo transtulisti, ut pro peccatis nostris apud te fiducialiter intercedat. Per [eundem].

COMMUNION: Dilexisti iusticiam et odisti iniquitatem: [propterea unxit te deus, deus tuus].

POSTCOMMUNION: Concede misericors deus fragilitati nostre presidium, ut qui sancte dei genitricis requiem celebramus, intercessionis eius auxilio a nostris iniquitatibus resurgamus. Per eundem [dominum nostrum]. 


\section{B. First Vespers for the Assumption of the Virgin}

\section{Antiphons:}

1 Virgo prudentissima, quo progrederis, quasi aurora valde rutilans? Filia Syon, tota formosa et suavis es, pulchra ut luna, electa ut sol.

2 Beata progenies, unde Xpistus natus est; quam gloriosa virgo, que celi regem genuit.

3 Vidi speciosam sicut columbam, ascendentem desuper rivos aquarum cuius inestimabilis odor erat nimis in vestimentis eius, et circumdabant eam flores rosarum et lilia convallium.

4 Tota pulchra es, amica mea, et macula non est in te; favus distillans labia tua, mel et lac sub lingua tua, odor unguentorum tuorum super omnia aromata; iam enim hyemps transiit, ymber abiit et recessit, flores apparuerunt, vinee florentes odorem dederunt, et vox turturis audita est in terra nostra: Surge, propera, amica mea; veni de Libano, veni, coronaberis.

5 Anima mea liquefacta est, ut dilectus locutus est. Quesivi et non inveni; illum vocavi et non respondit michi. Invenerunt me custodes civitatis; percusserunt me et vulneraverunt me; tulerunt pallium meum custodes murorum. Filie Jerusalem, nunciate dilecto quia amore langueo.

Chapter: [Ecclesiasticus 24:11b-12; as at Mass] In omnibus requiem quesivi, et in hereditate domini morabor. Tunc precepit et dixit michi creator omnium; et qui creavit me requievit in tabernaculo meo.

Responsory: Styrps Yesse virgam produxit virgaque florem, et super hunc florem requievit spiritus almus. Verse: Virgo dei genitrix virga est; flos, filius eius. Et super. Gloria patri et filio et spiritui sancto. Et super.

Hymn:

Quem terra, pontus, ethera,

Colunt, adorant, predicant,

Trinam regentem machinam

Claustrum Marie baiulat.

Cui luna, sol, et omnia

Deserviunt per tempora

Perfusa celi gratia,

Grestant puelle viscera.

Beata mater munere,

Cuius supernus artifex,

Mundum pugillo continens,

Ventris sub archa clausus est.

Beata celi nuntio,

Fecunda sancto spiritu,

Desideratus gentibus

Cuius per alvum fusus est. Divisio. 


\section{Festschrift for ERNest SANDERS}

O gloriosa domina

Excelsa supra sydera

Qui te creavit provide

Lactasti sacro ubere.

Quod Eva tristis abstulit

Tu reddis almo germine

Intrent ut astra flebiles

Celi fenestra facta es.

Tu regis alti ianua

Et porta lucis fulgida

Vitam datam per virginem

Gentes redempte plaudite.

Gloria tibi, domine,

[Qui natus es de virgine,

Cum patre et sancto spiritu,

In sempiterna secula. Amen.]

Versicle: Post partum, virgo, inviolata permansisti. [Response: Dei genitrix, intercede pro nobis.]

Magnificat antiphon: Paradisi porta per Evam cunctis clausa est, et per Mariam virginem iterum patefacta est, alleluya. Euouae. Ps. Mag[nificat].

W. In sanguine domini nostri lhesu Xpisti quem a [ex] se incarnatum nobis genuit salvatorem.

Oratio: Deus qui virginalem aulam beate Marie in qua habitares eligere dignatus es: da quesumus: ut sua nos defensione munitos iocundos faciat sue interesse festivitati. Qui vivis [et regnas cum deo patre].

[Benedicamus domino. R. Deo gratias.]

\section{Mass for the Assumption of the Virgin}

INTROIT: Gaudeamus omnes in domino, diem festum celebrantes sub honore Marie virginis: de cuius assumptione gaudent angeli, et collaudant filium dei. $\mathbb{W}$. Eructavit cor meum verbum bonum: dico ego opera mea regi. Gloria patri.

COLLECT: Veneranda nobis, domine, huius diei festivitas opem conferat salutarem, in qua sancta dei genitrix mortem subiit temporalem, nec tamen mortis nexibus deprimi potuit, que filium tuum dominum nostrum Jhesum Xpistum de se genuit incarnatum. Qui tecum [vivit].

EPISTLE: Lectio libri sapientie [Ecclesiasticus 24:11b-13, 15-20].

In omnibus requiem quesivi, et in hereditate domini morabor. Tunc precepit et dixit michi creator omnium, et qui creavit me requievit in tabernaculo meo. Et dixit michi: In Jacob inhabita, et in Israel hereditare, et in electis meis mitte radices. 
Et sic in Syon firmata sum, et in civitate sanctificata similiter requievi. Et in Jerusalem potestas mea. Et radicavi in populo honorificato, et in partes dei mei hereditas illius, et in plentitudine sanctorum detentio mea.

Quasi cedrus exaltata sum in Libano: et quasi cypressus in monte Syon. Quasi palma exaltata sum in Cades: et quasi plantatio rose in Jericho. Quasi oliva speciosa in campis: et quasi platanus exaltata sum iuxta aquam in plateis. Sicut cynnamomum et balsamum aromatizans: odorem dedi. Quasi myrra electa: dedi suavitatem odoris.

GRADUAL: Benedicta et venerabilis es, virgo Maria: que sine tactu pudoris inventa es mater salvatoris. $\mathrm{W}$. Virgo dei genitrix, quem totus non capit orbis, in tua se clausit viscera factus homo.

ALLELULA: Assumpta est Maria in celum: gaudent angeli et collaudantes benedicunt dominum.

ALLELUIA: Post partum, virgo, inviolata permansisti: dei genitrix, intercede pro nobis.

ALLELUIA: Per te, dei genitrix, nobis est vita perdita data que de celo suscepisti prolem et mundo genuisti salvatorem.

ALLELUIA: Ora pro nobis, pia virgo Maria, de qua Xpistus natus est nobis, ut peccatoribus sit misertus.

ALLELUIA: Virga Iesse floruit: virgo deum et hominem genuit: pacem deus reddidit, in se reconcilians yma summis.

ALLELUIA: Hodie Maria virgo celos ascendit; gaudete, quia cum Xpisto regnat in eternum.

\section{PROSA:}

1a. Letabundus / exultet fidelis chorus, / alleluya.

1b. Regem regum / intacte profudit thorus; / res miranda.

2a. Angelus consilii / natus est de virgine, / sol de stella,

2b. Sol occasum nesciens, / stella semper rutilans, / semper clara.

3a. Sicut sydus radium, / profert virgo filium / pari forma:

3b. Neque sydus radio, / neque mater filio / fit corrupta.

4a. Cedrus alta libani / conformatur ysopo / valle nostra.

4b. Verbum, mens altissimi / corporari passum est / carne sumpta.

5a. Ysaias cecinit; / synagoga meminit, / nunquam tamen desinit / esse ceca.

5b. Si non suis vatibus, / credat vel gentilibus / Sibillinis versibus / hec predicta.

6a. Infelix propera, / crede vel vetera; / cur dampnaberis, gens misera?

6b. Quem docet littera, / natum considera; / ipsum genuit puerpera.

Amen. 
GOSPEL: Secundum Lucam [Luke 10:38-42]. In illo tempore: Intravit Ihesus in quoddam castellum, et mulier quedam Martha nomine excepit illum in domum suam. Et huic erat soror, nomine Maria, que etiam sedens secus pedes domini: audiebat verbum illius. Martha autem satagebat circa frequens ministerium. Que stetit et ait, Domine: non est tibi cure quod soror mea reliquit me solam ministrare? Dic ergo illi: ut me adiuvet. Et respondens dixit illi dominus: Martha, Martha, solicita es: et turbaris erga plurima. Porro: unum est necessarium. Maria optimam partem elegit: que non auferetur ab ea.

OFFERTORY: Beata es, virgo Maria, que dominum portasti creatorem mundi genuisti qui te fecit et in eternum permanes virgo.

OFFERTORY: Felix namque es, sacra virgo Maria, et omni laude dignissima: quia ex te ortus est sol iusticie, Xpistus deus noster, alleluya.

OFFERTORY: Ave Maria, gratia plena, dominus tecum: benedicta tu in mulieribus, et benedictus fructus ventris tui.

SECRET: Subveniat, domine, plebi tue dei genitrices oratio, quam et si pro conditione carnis migrasse cognoscimus, in celesti gloria apud te pro nobis orare sentiamus. Per e[undem Dominum].

PREFACE: ... Et te in assumptione beate et gloriose semperque virginis Marie....

COMMUNION: Regina mundi et domina virgo Maria perpetua, intercede pro nostra pace et salute, que genuisti Xpistum dominum salvatorem omnium.

COMMUNION: Vera fides geniti purgavit crimina mundi, et tibi virginitas inviolata manet.

COMMUNION: Beata viscera Marie virginis, que portaverunt eterni patris filium.

POSTCOMMUNION: Mense celestis participes effecti imploramus clementiam tuam, domine deus noster, ut qui festa dei genitricis colimus, a cunctis malis imminentibus eius intercessionibus liberemur. Per e[undem]. 


\section{Mass for the Nativity of the Virgin}

INTROIT: Gaudeamus omnes in domino, diem festum celebrantes sub honore Marie virginis: de cuius nativitate gaudent angeli, et collaudant filium dei. W. Eructavit cor meum verbum bonum: dico ego opera mea regi. Gloria patri.

ORATIO: Supplicationem servorum tuorum deus miserator exaudi, ut qui in nativitate dei genitricis et virginis congregamur, eius intercessionibus a te de instantibus periculis eruamur. Per e[undem].

EPISTLE: Lectio libri sapientie [Ecclesiasticus 24:23-31].

Ego quasi vitis fructificavi suavitatem odoris: et flores mei fructus honoris et honestatis. Ego mater pulchre dilectionis et timoris: et magnitudinis sancte spei. In me gratia omnis vie et veritatis: in me omnis spes vite et virtutis. Transite ad me, omnes qui concupiscitis me: et a generationibus meis implemini. Spiritus enim meus super mel dulcis: et hereditas mea super mel et favum. Memoria mea in generationes seculorum. Qui edunt me adhuc esurient: et qui bibunt me adhuc sitient. Qui audit me non confundetur: et qui operantur in me non peccabunt. Qui elucidant me vitam eternam habebunt.

GRADUAL: Benedicta et venerabilis es, virgo Maria: que sine tactu pudoris inventa es mater salvatoris. $\mathbb{Z}$. Virgo dei genitrix, quem totus non capit orbis, in tua se clausit viscera factus homo.

ALLELUIA: Nativitas gloriose virginis Marie, ex semine Abrahe, orta de tribu Iuda, clara ex stirpe David.

\section{PROSA:}

1a. Hac clara die turma / festiva dat preconia

1b. Mariam concrepando / symphonia nectarea,

2a. Mundi domina / que est sola, / castissima virginum regina,

2b. Salutis causa, / vite porta / atque celi referta gratia.

3a. Nam ad illam sic nuncia / olim facta angelica:

3b. "Ave, Maria, gratia / dei plena per secula,

4a. Mulierum pia / agmina intra / semper benedicta,

4b. Virgo et gravida, / mater intacta, / prole gloriosa."

5a. Cui contra Maria / hec reddit famina:

5b. "In me quomodo tua / iam fient nuncia?

6a. Viri novi nullam / certe copulam,

6b. Ex quo atque nata / sum incorrupta."

7a. Diva missus ita / reddit affata:

7b. "Flatu sacro plena / fies, Maria,

8a. Nova efferens gaudia / celo, terre nati per exordia;

8 b. Intra tui uteri claustra / portas, qui gubernat ethera.

9. Omnia qui dat tempora / pacifica." 
GOSPEL: Initium sancti evangelii secundum Matheum [Matthew 1:1-16]. Liber generationis Ihesu Xpisti filii David, filii Abraham. Abraham genuit Ysaac. Ysaac autem genuit Jacob. Jacob autem genuit Judam, et fratres eius... Nathan autem genuit Jacob. Jacob autem genuit Joseph virum Marie, de qua natus est Ihesus, qui vocatur Xpistus. Credo.

OFFERTORY: Beata es, virgo Maria, que dominum portasti creatorem mundi genuisti qui te fecit et in eternum permanes virgo.

SECRET: Unigeniti tui domine nobis succurrat humanitas, ut qui natus de virgine, matris integritatem non minuit, sed sacravit; in nativitatis eius sollempniis, a nostris nos piaculis exuens, oblationem nostram sibi faciat acceptam. Qui tecum vivit.

PREFACE: ... Et te in nativitate beate [et gloriose semperque virginis Marie]....

COMMUNION: Regina mundi et domina virgo Maria perpetua, intercede pro nostra pace et salute, que genuisti Xpistum dominum salvatorem omnium.

POSTCOMMUNION: Sumpsimus domine celebritatis annue votiva sacramenta: presta, quesumus, ut et temporalis nobis vite remedia prebeant et eterne. Per [dominum].

Manuscript sources of Paris use for the liturgical texts:

Mass texts: Paris, Bibliothèque Nationale, lat. 1112, 15615, and 9441.

Vespers texts: Paris, Bibliothèque Nationale, lat. 15182. 


\section{Appendix II}

\section{A. Motets for the Vigil of the Assumption}

\section{37 Gradual for Vigil Mass: Propter veritatem X. Audi filia}

Propter veritatem et mansuetudi- Because of truth and meekness and nem et iusticiam, et deducet te justice, thy right hand shall conduct mirabiliter dextera tua.

W. Audi, filia, et vide, et inclina aurem tuam, quia concupivit rex speciem tuam. thee wonderfully. W. Hear, $O$ daughter, and see, and incline thy ear, for the king hath desired thy beauty.

Motet 448: O Maria, maris stella / Veritatem

a3 in $F, 397 \mathrm{v}(1,25)$, and $W_{2}, 125(1,3)$ [no source clausula]

O Maria, maris stella,

Plena gratie,

Mater simul et puella,

Vas munditie,

Templum nostri redemptoris,

Sol iusticie,

Porta celi, spes reorum,

Thronus glorie,

Sublevatrix miserorum,

Vena venie,

Audi servos te rogantes,

Mater gratie,

Ut peccata sint ablata

Per te hodie,

Qui te puro laudant corde

In veritate.
O Mary, star of the sea,

full of grace,

At once both mother and maiden, vessel of cleanliness,

Temple of our Redeemer, sun of justice,

Gate of heaven, hope of sinners, throne of glory,

Supporter of the wretched, fountain of forgiveness,

Hear thy servants beseeching thee, mother of grace,

That (their) sins may be taken away through thee this day,

Those who praise thee with a pure heart in truth. ${ }^{22}$

22 Translations of motet texts not credited to Gordon Anderson (The Latin Compositions in Fascicules VII and VIII of the Notre Dame Manuscript Wolfenbüttel, Helmstadt 1099 (1206), part 1) are my own. 
Motet 478: Audi, filia egregia / Filia

a2 in $F, 408 \mathrm{v}(2,30)$ [no source clausula]

Audi, filia egregia,

Audi, parens paris nescia,

Quante forme splendis gloria,

Quanta regis viges gratia,

Qui creavit omnia.

Pande brachia pia,

Quia tot instant naufragia.

Servos reconcilia;

De mundi miseria

Per te transeant ad gaudia

Celestia.
Hear, illustrious daughter,

Hear, mother unaware of a partner, You shine with glory of such great beauty, you thrive on such great grace of the King who created all things. Extend thy merciful arms, because so many shipwrecks impend.

Reconcile thy servants; from the misery of the world through thee let them pass to celestial joys.

M 54 Alleluia for Vigil Mass (if Sunday): Alleluia Veni electa mea

Veni electa mea et ponam te in thronum meum, quia concupivit rex speciem tuam.
Come, my chosen one, and I will place thee upon my throne, for the king hath desired thy beauty.

Motet 529: Quia concupivit vultum / Quia concupivit rex a2 in $F, 405(2,19)$, and $W_{2}, 152 \mathrm{v}(2,14)$

Quia concupivit

Vultum rex et decorem,

Virgineum

Et roseum,

Serves eum florem.

Vas exuet

Te luteum

Et induet

Ethereum

Te splendorem.
Because the king hath greatly desired thy beauty and countenance, virginal and rosy, thou shalt preserve that flower. The earthly vessel shall fall away from thee and the heavenly [vessel] shall clothe thee in splendor.

\section{B. Motets for the Responsory Styrps Yesse}

O 16 Vespers responsory Styrps Yesse W. Virgo dei

Styrps Yesse virgam produxit virga- The stem of Jesse produced a twig que florem, et super hunc florem and the twig a flower, and above this requievit spiritus almus. flower rested the nourishing Spirit. V. Virgo dei genitrix virga est, flos filius eius. The Virgin Mother of God is the twig; \{ the flower, her son. 
Motet 647/648: Stirps Yesse / Virga cultus / Flos filius eius a3 double motet in $F, 409 \mathrm{v}(2,33-34)$ [a3 source clausula]

\section{Motetus}

Virga, cultus nescia

dum floruit,

Quam celestis gratie

ros imbuit,

Ree virge diluit

contagia.

Glorie

Fructum flos exhibuit;

Trabeam

carneam

Verbum induit;

Sol levi nume latuit.

\section{Triplum}

Stirps Iesse progreditur;

Virga prodit celitus;

Ex virga flos producitur.

Spiritus

Septiformis gratie

Florem perficit

Fructu glorie;

Flos electos reficit,

Cuius odor mentium

Remedium.
A small stem, not knowing the hand of the cultivator while it flourished, which the dew imbued with heavenly grace, washed away all the filth from sinful man.

The flower brought forth the fruit of glory; the Word put on a stately robe of flesh, and now the Sun lies hidden behind but a transparent cloud.

(Anderson, 1:97-98)

The stem of Jesse flourishes, and from heaven a small twig produces, and from this twig a flower blooms.

The Spirit of seven-fold grace makes perfect the flower through the fruit of grace, and the flower, whose odor is a remedy of [troubled] minds, restores the elect.

(Anderson, 1:98)

Motet 649: Candida virginitas / Flos filius eius [= Motet 648] a2 in $W_{2}, 145 \mathrm{v}(2,3)$ [a3 source clausula]

Candida virginitas

ut lilium,

Candida fecunditas

per filium,

Iubilet iocunditas

humilium,

Castitas,

Caput hostis conterit, Atrium patrium

Aperit, per id

Fides et spes et caritas.
$O$ virginity, spotless as

a lily;

O spotless conception, through the Son may all the joy of the humble shout forth.

O chastity, thou hast crushed the head of the enemy and opened the heavenly halls; through it come Faith, Hope, and Love.

(Anderson, 1:97) 
Motet 665: Flos ascendit de radice / Flos filius eius a2 in $W_{2}, 161(2,31)$

Flos ascendit de radice,

Virgo lesse mistice,

Prophetie

Versa vice

Verbum respice,

Cum (populo) respice

Partu pro felice

Prolis unice

Futurum despice

Iudaice

Plebis in unice,

Ubi catholice,

Virga dei genitrice,

Facta si vivifice,

Dic melice

Flos filius eius.
A flower ascended from the root; O mystic Virgin of Jesse's stem, look back again

at the word

of prophecy;

look back with [thy people]

and regard the happiness

of thy only Son

and look upon the future

of Judah,

thy own people,

whence was sprung the stem

of the universal Mother of God;

if quickening with life, speak approvingly on their behalf, O Flower, her Son.

(Anderson, 1:187)

Motet 669: Ave, rosa novella / Flos filius eius $\mathrm{a} 2$ in $W_{2}, 178 \mathrm{v}(2,51)$ [no source clausula]

Ave, rosa novella,

Rorem stillans et mella,

Maria, maris stella,

Medicinalis cella,

Dei mater et puella,

Te querentium

Inimici seda bella

Post exilium,

(Hoc obsecra in procella)

Regem omnium;

Tu pro nobis interpella

Tuum filium.
Hail, new rose-bud,

distilling dew and honey,

Mary, star of the sea, store house of medicine,

Mother and Daughter of God,

Put down the wars waged by

the enemies of those seeking thee,

and after this exile,

[seated in glory next to]

the King of all,

do thou interecede with thy son

for us.

(Anderson, 1:279)

O 16 Procession after Terce: Styrps Yesse W. Virgo dei

Styrps Yesse virgam produxit virga- The stem of Jesse produced a twig que florem, et super hunc florem requievit spiritus almus. and the twig a flower, and above this flower rested the nourishing Spirit.

$V$. Virgo dei genitrix virga est, flos filius eius.

The Virgin Mother of God is the twig; the flower, her Son. 
Motet 660: O vere lucis aurora / Flos filius eius a2 in $W_{2}, 175 \mathrm{v}(2,45)$ [source clausula in StV]

O vere lucis aurora, Lucida

Fulgeas aura rora, O fulgida;

Nobis placa placida

Et pacida,

$O$ virgo natum decora,

Angelorum decor ora,

Ne Sansonis Dalida

Nos valida

Fervida

Figat, fervida

Figit in ora.
O Morning Star of true light, shine brightly, $\mathrm{O}$ dewy air, $\mathrm{O}$ shining one, grant us thy peace in reconciliation, and grant, $O$ pure Virgin, the gift of thy Son, and beseech, $O$ most elegant of the angels, that unlike Samson, we will not fall into the wiles of Delilah; grant us strength and strengthen our fervor, and direct the fervor of our lips.

(Anderson, 1:251)

Motet 670: Virga, virgo regia / Flos filius eius a2 in $W_{2}, 189 \mathrm{v}(2,76)$ [no source clausula]

Virga, virgo regia, Mater regis filia, Fax previa, Vite federa, Spes pervivia, Veni rei venia; Fac nobis sit pius Tua per suffragia Civis flos filius.
Stem, royal Virgin, Mother and Daughter of God, torch lighting the way, covenant of life, hope everlasting, come, pardon of sinners; grant through thy intercession that the Flower, thy holy Son, be present with us.

(Anderson, 1:360)

\section{Motets for the Benedicamus Domino}

BD I Benedicamus Domino at First Vespers

Motet 655: Virgo singularis / [Domino] a2 in $F, 414(2,45)$ ( $\mathrm{T}=E[$ ius $]$ from $\mathrm{O} 16)$

Virgo singularis, Respice quod quero, Per te, stella maris, Gratie spem gero. Ianua salutis, Ad te propero
O Virgin remarkable, attend to what I seek; through thee, Star of the Sea, I entertain hope of grace.

Gateway of safety, To thee I hasten, 


\section{Festschrift for ERNest SANDERS}

Et fragmenta iuventutis

Tibi offero.

Te considero,

Quid sim, et agnosco,

Unde licet sero

Veniam deposco.

Per te potero,

Quod desidero,

Virgo, que sincero

Paris utero.

Tuus sum et ero,

De te non despero,

Quicquid egero. and remnants of youth

I offer to thee.

Thee I contemplate,

Why I am, and I recognize

from whom, although (too) late,

I claim pardon.

Through thee I shall have acquired

that for which I long,

O Virgin, thou who from a pure

womb giveth birth.

Thine I am and shall be;

Of thee I despair not, whatever I lack.

Motet 760a: Ave gloriosa mater / (Domino)

a2 conductus (no $\mathrm{T}$ ) in $W_{2}, 140(1$, conductus 3$)$ [no source clausula] [a3 motet in other sources]

Ave, gloriosa

Mater salvatoris,

Ave, speciosa

Virgo, flos pudoris,

Ave, lux iocosa,

Thalamus splendoris,

Ave, preciosa

Salus peccatoris.

Ave, vite via,

Casta, munda, pura,

Dulcis, mitis, pia,

Felix creatura.

Parens modo miro

Nova paritura,

Virum sine viro,

Contra carnis iura.

Virgo virginum,

Expers criminum,

Decus luminum,

Celi domina,

Salus gentium,

Spes fidelium,

Lumen cordium,

Nos illumina.
Hail, glorious

Mother of the Savior,

Hail, comely Virgin,

flower of purity,

Hail, happy light,

bridal chamber of splendor,

Hail, precious

salvation of the sinner.

Hail, pathway of life, chaste, clean, and pure, sweet, mild, and merciful, happy creature.

Parent in wonderful manner of a new kind of birth, of man without man, against the law of the flesh.

Virgin of virgins,

free from guilt, ornament of lights, mistress of heaven, salvation of the people, hope of the faithful, light of hearts, enlighten us. 
Nosque filio

Tuo tam pio,

Tam propitio

Reconcilia,

Et ad gaudia

Nos perhennia

Duc prece pia

Virgo Maria.
And reconcile us

to thy Son,

so just and

so merciful;

and lead us

to joy everlasting

through thy pious prayer,

O Virgin Mary.

\section{Motets for the Gradual Benedicta}

\section{32 Gradual Benedicta W. Virgo dei}

Benedicta et venerabilis es, virgo Maria: que sine tactu pudoris inventa es mater salvatoris. V. Virgo dei genitrix, quem totus non capit orbis, in tua se clausit viscera factus homo.
Blessed and venerable art thou, $\mathrm{O}$ Virgin Mary, who without the touch of shame art become Mother of the Savior. V. Virgin Mother of God, he whom the whole world cannot hold, in thy womb was enclosed and became man.

Motet 411: O Maria, mater pia, mater / Virgo [= Motet 412]

a3 in $F, 393(1,18)$

a2 in $W_{2}, 183 \mathrm{v}(2,64)$

O Maria, mater pia,

Mater salvatoris,

Tu nos audi, tue laudi

Grata sit laus oris,

Turris regis glorie,

Templum redemptoris,

Thalamus munditie,

Signaculum pudoris.

Fons misericordie,

Virgo vernans specie

In celi solio,

$\mathrm{O}$ parens singularis

Salvo gremio,

Digna puellaris

Partus gaudio.

In hoc dubio

Mundi nos navigio

A naufragio

Salva, stella maris.
O Mary, Holy Mother,

Mother of the Savior,

hear us, and let the praise of our

lips be acceptable unto thee,

$\mathrm{O}$ tower of the King of Glory, temple of the Redeemer, bridal bed of cleanliness and token of modesty. [Thou art] the fount of pity, the Virgin blooming in the glorious throne of Heaven! $O$ Mother of unique distinction, seemly and maidenly, in thy saving bosom is the spring of joy. In this world of doubt, save us, thy ship, from utter shipwreck, O star of the sea!

(Anderson, 1:44-45) 
Motet 412: Virgo plena gratie / Virgo [= Motet 411]

a3 in $W_{2}, 129 \mathrm{v}(1,9)$

a 2 in $W_{2}, 154 \mathrm{v}(2,18)$

Virgo plena gratie,

Thesaurus largitatis,

Oculus clementie,

Pupilla pietatis,

Porta patens venie,

Scala caritatis,

Oleum letitie,

Nomen suavitatis;

Tu commune canticum,

Propelleuma nauticum;

Clamant omnia

"Subveni Maria!"

Instant tempora,

Nova gravat hora,

Operarios

Plus abrevia

Dies hos Egyptios

Propter filios,

Virgo mater pia.

\author{
Virgin full of grace, \\ treasury of abundance, \\ eye of mercy, \\ ward of piety, \\ gate opening to pardon, \\ ladder of charity, \\ oil of joy, \\ name of sweetness; \\ thou art the universal song, \\ the driving breeze to seamen. \\ All things cry out, \\ "Come to our aid, O Mary!" \\ The times threaten; \\ the new hour oppresses; \\ shorten more speedily \\ these Egyptian Days \\ of labor, \\ for the sake of thy children, \\ $O$ devout Virgin Mother.
}

\section{Motet 417: Benedicta regia / Vingo}

a2 in $W_{2}, 145(2,2)$, and $W_{2}, 178 \mathrm{v}(2,52)$ [no source clausula]

Benedicta regia

Virgo venerabilis,

Mater honorabilis,

Eterni regis filia,

Viri tactus nescia,

Stella maris Maria,

Piis pia,

Inter animalia

Tua ligas fascia,

Quem non capit sensilis

Mundi via;

Tu nos duc ad gaudia

Patrie, dux amabilis.
Blessed royal

Virgin worthy of praise, Mother worthy of honor, daughter of the Eternal King, not knowing the touch of man, Mary, star of the sea, devoted to the holy; Thou tiest together the bands between all living things, Thou whom the path of the sensuous world has not degraded; lead us to the joys of the kingdom, O lovely leader. 
Motet 420: Mellea vite vinea / Virgo

a2 in $W_{2}, 190(2,78)$

Mellea

Vite vinea,

Vena venie,

Gratie

Lampas vitrea,

Legis vie

Linea

Aurea,

Lux etherea,

Tellus rosea,

Solium

Regium,

Virga turrera,

Mea spes, ave, dei

Mater virgo Iessea.

\author{
Honey-sweet \\ vine of life, \\ vein of pardon, \\ transparent \\ lamp of grace, \\ golden lineage \\ of the way \\ of the Law, \\ ethereal light, \\ rosy earth, \\ royal \\ throne, \\ stem, frankincense, \\ my hope, Hail! Mother of God, \\ Virgin from the stem of Jesse.
}

(Anderson, 1: 363)

Motet 422: O pia, capud hostis / Virgo a2 in $W_{2}, 191 \mathrm{v}(2,82)$ [no source clausula]

O pia,

Capud hostis veteris

Conteris,

Mater maris nescia, Maria,

Stella maris, inferis

Lucem [das] de superis,

Que rutilat pre ceteris

Previa

Spem salutis aperis.

Tu nobis sis propitia,

Ut de tua gratia

Mundi per hec maria

Iam passis naufragia

Detur portus miseris.
O Holy One, thou dost crush the head of the ancient enemy; Mother, not knowing man, Mary,

Star of the sea, to those below thou dost give light from above; thou who shineth more brightly than all others, by leading the way, thou dost open the hope of safety. Mayst thou be favorable towards us, that through thy grace the miserable who now suffer shipwreck though these seas of the world be given safe harbor.

\section{E. Motets for the Alleluia Hodie Maria Virgo}

M 34 In place of responsory at Second Vespers: Alleluia Hodie Maria virgo Hodie Maria virgo celos ascendit; Today the Virgin Mary ascends the gaudete, quia cum Christo regnat heavens; rejoice, for with Christ she in eternum. reigns in eternity. 
Motet 437: Flos de spina rumpitur / Regnat

a3 in $F, 393 \mathrm{v}(1,19)$

a2 in $W_{2}, 147(2,6)$ and $180(2,56)$

Flos de spina rumpitur,

Spina caret

Flos et aret,

Sed non moritur.

Vite florem

Per amorem

Flos complectitur,

Cuius ex solatio

Sic reficitur

In vigore proprio,

Quod non patitur.

Virgo de Iudea

Sursum tollitur,

Testea

Fit aurea

Corporea sanctitur,

Laurea

Redemitur

Mater beata

Glorificata.

Per cuncta mundi climata

Civium

Consortium

Celestium

Laude resolvitur;

Oritur

Fidelibus

Dies iubilei;

Dabitur

Amplexibus

Marie quies dei.

Non ero

De cetero

Iactatus a procella:

Ecce, maris stella

Aurem pii filii

Precibus impregnat,

Que stellato solio

Cum filio regnat.
A bud bursts forth from a thorn.

The flower lacks a thorn

and withers

but does not die.

Through love,

the flower embraces

the flower of life,

from whose nurture

it thus revives

into its proper vigor

because it has suffered no taint.

A Virgin from Judea

is raised up high,

and an earthly body,

becoming golden,

is sanctified;

the blessed Mother

is encircled

with laurel wreath

and is glorified.

Throughout all the regions of the world the praise

of the living

heavenly consort

resounds.

A day of joy

has come

to the faithful,

and the peace of God

is granted to the followers

embracing Mary.

I shall not be cast down from

amongst the band of the faithful

by the tempest,

for lo, the Star of the Sea

fills with prayers

the ear of the holy Son-

she who with the Son rules

in the starry throne.

(Anderson, 1:113) 


\section{Motet 441: Hodie Marie concurrant / Regnat}

a3 in $F, 394 \mathrm{v}(1,21)$

\section{Hodie Marie}

Concurrant laudi mentes pie;

Vocis armonie

Concordent vite melodie.

Qua completa die,

Virgo cursum vie

Regnat in throno glorie.

Mater ergo pia,

Salutis nostre spes et via,

Previa,

Precum gratia

Reconcilia

Servos tuos filio,

Ne sub iudicio

Libretur actio.

Veniam procura,

Ne requirat iura

Iudicis censura.
Today let pious minds

join together in praise of Mary;

let the concords of sound

be in harmony with the melody of life.

For the day being completed, the Virgin, on the Throne of Glory, rules the course of the journey.

Therefore holy Mother,

hope and path of our safety,

leading the way

with grace before,

reconcile

thy servants to the Son

lest that under judgment

indictment be hurled.

Procure pardon,

lest censure seek

the rigors of judgment.

Motet 442: Rex pacificus unicus / Regnat a2 in $F, 402 \mathrm{v}(2,10)$, and $W_{2}, 153(2,15)$

Rex pacificus,

Unicus,

Matris unice

Honorifice,

Ministrantibus

Celi civibus

Dat solium

Egregium

Pre ceteris,

De cuius muneris

Presentia

Militia

Celi publice

Gaudet quia regia

Styrpis davitice

Proles ad participium

Regni iungitur

Civium consortio

Verbi beneficio;
The King of Peace,

in marvelous fashion

born of a mother

with signal honor,

gives to his

ministering dwellers

of the heavens,

before all others,

his glorious throne,

in the reception

of which

the whole company

of the heavens

rejoices because a royal child

of David's line

is joined in participation

of the kingdom

to the heavenly consorts

by the blessing of the Word; 
Ubi mater filium,

Patrem videt filia

Summa cum letitia;

Ubi summo premio

Cum electis fruitur;

Ubi noscit et noscitur,

Ubi pane patrie

Pascitur;

Ubi regis glorie

Cernitur

Fascies;

Ubi quies

Quietem sequitur;

Ubi sanctorum acies

Regnat. where the Mother sees her Son and the Daughter her Father with the utmost joy;

where the elect enjoy

the greatest reward;

where one knows and is known;

where one feasts

on heavenly bread;

where the face

of the King of Glory

is seen;

where rest

follows quiet;

where the whole company of saints rules.

(Anderson, 1:142) 